\title{
PERANCANGAN E-COMMERCE PADA JEYS CORNER UNTUK MENINGKATKAN PENJUALAN MENGGUNAKAN METODE BUSINESS MODEL CANVAS
}

\author{
Maulana Rifki Haiqal ${ }^{1)}$, Yuliazmi ${ }^{2)}$ \\ Sistem Informasi, Fakultas Teknologi Informasi, Universitas Budi Luhur \\ J1. Raya Ciledug, Petukangan Utara, Kebayoran Lama, Jakarta Selatan 12260 \\ E-mail : rifhaiqal@gmail.com ${ }^{1)}$, yuliazmi@budiluhur.ac.id ${ }^{2)}$
}

\begin{abstract}
Abstrak
Jeys Corner merupakan sebuah toko online yang menjual produk perawatan kulit. Jeys Corner memasarkan produknya melalui media sosial Instagram. Dengan pesatnya perkembangan teknologi saat ini, penjualan pada website E-Commerce digunakan untuk kebutuhan bisnis yang cepat dan tepat. Masalah yang terjadi pada Jeys Corner adalah belum maksimalnya pemasaran yang digunakan, sering membludaknya antrian pertanyaan mengenai produk di aplikasi chat di Jeys Corner dikarenakan tidak adanya informasi yang lengkap mengenai produk yang dijual pada Jeys Corner. Adapun pendekatan yang digunakan penulis yaitu wawancara, observasi, analisa dokumen, dan studi literatur. Tools yang digunakan dalam penelitian ini adalah wordpress untuk template website, content management system untuk sistem yang digunakan oleh wordpress tersebut. Metode yang digunakan untuk penelitian ini menggunakan Business Model Canvas. Hasil akhir yang dicapai adalah prototipe sistem e-commerce untuk mengatasi masalah yang terdapat pada Jeys Corner.
\end{abstract}

Kata kunci: E-Commerce, Content Management System, Produk Perawatan Kulit

\section{PENDAHULUAN}

Di dunia Teknologi Informasi, E-Commerce bukan cara baru dalam proses jual beli secara elektronik. Karena E-Commerce berkembang di Indonesia sejak 1996. Namun pada era ini, yang mana pada saat ini juga kita sedang berada pada fase Revolusi Industri 4.0. E-Commerce berkembang sangat pesat khususnya untuk pelaku usaha. Mulai dari usaha perseroan maupun usaha perorangan yang banyak berkembang sebagai bisnis rumahan berlomba-lomba untuk menjadi yang terdepan untuk mengembangkan sistem $E$ Commerce mereka. E-Commerce menarik karena dapat memberikan informasi dalam bentuk yang lebih menarik di sisi pengguna maupun admin dan dapat diakses setiap saat secara online. Banyaknya manfaat serta kemudahan dalam E-Commerce ini dapat menarik minat untuk dimanfaatkan oleh para pelaku dalam kegiatan jual beli. Pelayanan teknologi yang semakin tinggi pada saat ini menuntut layanan yang semakin mudah, cepat, dan praktis. Konsep toko online menyediakan banyak kemudahan dan kelebihan jika dibandingkan dengan konsep belanja yang tradisional.

Jeys Corner adalah usaha bisnis rumahan yang bergerak pada bidang penjualan produk yang dikhususkan untuk perawatan kulit. Jeys Corner memasarkan semua produknya di media sosial instagram yang beralamatkan di username @jeyscorner.id, dimana para pelanggan yang berminat untuk membeli produk Jeys Corner diharuskan untuk mengujungi media sosial dari Jeys Corner. Jeys Corner mendapat produknya dari distributor beberapa merk besar produk

kesehatan kulit. Pemilik dan pengelola dari Jeys Corner adalah seorang mahasiswi aktif yang sering kali mendapat waktu kuliah yang bersamaan dengan munculnya banyak pertanyaan dari pelanggan mengenai produk yang dijualnya hingga sering kali para pelanggan mengurungkan niatnya untuk membeli produk Jeys Corner.

Untuk memecahkan masalah ini, sebagai penulis saya ingin mengimplementasikan sistem E-Commerce berbasis web pada Jeys Corner. Dengan adanya sistem E-Commerce berbasis web ini, akan membantu kendala yang ada pada Jeys Corner. Pelanggan akan dapat mengakses informasi mengenai produk Jeys Corner yang dijual tanpa harus campur tangan pemilik atau pengelola Jeys Corner secara aktif. Selain itu, dengan adanya sistem E-Commerce berbasis web ini, Jeys Corner dapat juga memperluas jangkauan pemasaran tanpa harus menghabiskan terlalu banyak waktu, biaya, dan tenaga sehingga hal tersebut juga dapat berdampak pada peningkatan penjualan yang terjadi di Jeys Corner.

\section{METODE PENELITIAN}

2.1 Langkah-langkah penelitian

a. Perumusan Masalah

Perumusan masalah yang ada pada toko JeysCorner adalah hasil dari kegiatan wawancara dan observasi langsung kepada owner dari JeysCorner.

b. Menentukan Metodologi Penelitian

Langkah ini dilkukan untuk menentukan metodologi apa yang bisa digunakan dalam menyelesaikan masalah penelitian. Metodologi yang digunakan adalah berupa Business Model Canvas (BMC).

c. Analisis Sistem Berjalan 
Pada langkah ini, peneliti menganalisa proses bisni sistem berjalan menggukan tool activity diagram.

d. Studi Literatur

Penelitian yang terdapat di bawah ini melakukan studi literatur dari berbagai referensi yang sesuai dengan permasalahan yang diamati oleh penulis. Studi ini dilakukan melalui jurnal yang dijadikan sebagai acuan pada kegiatan penelitian ini.

1. Menurut penelitian dari (Elinawati dan Muhammad, 2015) dengan judul "Perancangan EBisnis pada Toko Alya Gorden Dengan Menggunakan Konsep Content Management System (CMS). Toko Alya Gorden adalah toko yang bergerak dibidang gorden, seperti seprai dan segala perlengkapannya. Pemasaran Toko Alya ini masih menggunakan sistem manual sehingga konsumennya terbatas. Berkaitan dengan masalah tersebut, pengelolaan konten web secara continue menjadi hal yang sangat penting dalam pengembangan web. Salah satu cara untuk memecahkan permasalahannya yaitu dengan mernerapkan Content Management System (CMS) dengan tujuan untuk memberikan kemudahan bagi pembisnis dalam mengembangkan usahanya agar tercapai dengan tujuan yang diharapkan.

2. Menurut penelitian yang dilakukan oleh (Jogjakarta Intelligent System Association, Indonesian Computer and Universitas Gadjah Mada. Departemen Ilmu Komputer dan Elektronika, 2015) yang berjudul "Pengembangan Model Cyber Cluster E-Commerce Berbasis CMS dan SEO Produk UMKM" Usaha Mikro Kecil dan Menengah (UMKM) begitu banyak dominan yang tersebar pada setiap daerah atau Kabupaten di Indonesia, namun belum dapat berkembang dengan hasil yang menggembirakan, sebagian besar UMKM memiliki permasalahan utama yaitu keterbatasan kualitas Sumber Daya Manusia (SDM) dan lemahnya jaringan usaha yaitu keterbatasan penetrasi kualitas, permasalahan yang sering dihadapi oleh UMKM adalah terbatasnya jumlah dan jangkauan pemasaran dan penjualan produkya. Begitu juga persaingan produk sejenis dapat terjadi oleh antar produk local atau produk yang dating dari luar. Pada penelitian ini telah melakukan penelitian pengembangan model $E$ Commerce dengan teknik cyber cluster berbasis CMS dan SEO. Dengan penerapan metode SEO On-page dan Off-page serta CMS pada beberapa kelompok website UMKM.

\subsection{Teknik Analisis Data}

Teknik analisis data adalah salah satu langkah yang menentukan dari sebuah penelitian, karena analisa data berfungsi untuk menyimpulkan hasil dari penelitian, mengolah data untuk dijadikan informasi, sehingga karakteristik atau sifat-sifat data dapat dengan mudah dipahami dan bermanfaat untuk menjawab masalah-masalah yang berkaitan dengan kegiatan penelitian.

1. Analisa Masalah

Analisa Masalah adalah kajian sementara untuk mengetahui penyebab timbulnya masalah dengan cara observasi dan wawancara oleh penulis dalam memetakan masalah yang terdapat pada penelitian ini yang terjadi di Jeys Corner.

2. Analisa Proses Bisnis

Dalam tahap ini penulis melakukan analisa proses bisnis yang ada dan mempelajari apa yang akan dikerjakan, serta identifikasi kebutuhan, alat yang digunakan adalah activity diagram dan use case diagram.

3. Analisa Perancangan Sistem

Dalam tahap ini penulis merancang sistem secara rinci berdasarkan hasil analisa terhadap sistem yang telah ada, sehingga menghasilkan model sistem baru yang diusulkan ke pihak Jeys Corner. Tools yang digunakan dalam perancangan sistem yaitu: Class Diagram, rancangan layar dan System Sequence Diagram, dan IFML.

\subsection{Bussines Model Canvas}

Bussines Model Canvas adalah sebuah metode yang digunakan oleh penulis untuk menggambarkan, mendeskripsikan, menganalisa, dan merancang model bisnis pada suatu perusahaan [6].

Berikut adalah penjelasan 9 kolom yang ada pada Business Model Canvas, diantaranya adalah: Gambar yang terdapat pada gambar 1 adalah gambar dari template Business Model Canvas.



Gambar 1 : Business Model Canvas

\section{ANALISA DAN PEMBAHASAN}

\subsection{Proses Bisnis Usulan}

a. Proses Pemesanan Produk

Pelanggan yang akan membeli produk dari Jeys Corner mengunjungi website Jeys Corner untuk melihat produk yang ada pada Jeys Corner. Kemudian pelanggan memilih menu shop dan memilih produk yang diinginkan. Kemudian pelanggan memilih tombol add to cart pada produk yang diinginkan, dan jika sudah selesai memilih barang yang ingin dibeli pelanggan dapat memilih tombol view cart dan menentukan jumlah produk yang akan di beli dan kemudian memilih tombol 
checkout. Ketika pelanggan berada di halaman form checkout, pelanggan mengisi billing details dan memilih jasa pengiriman yang disediakan oleh Jeys Corner lalu jika data yang disiikan pada form checkout sudah benar menurut sistem dan pelanggan itu sendiri, maka pelanggan bisa memilih tombol place order. Pelanggan akan dialihkan ke halaman yang berisikan no rekening dari admin Jeys Corner dan jumlah yang harus ditransfer sesuai jumlah harga yang dibeli pelanggan tersebut, dan juga pelanggan akan mendapat email yang berisikan invoice pembelian. Setelah itu sistem dari website Jeys Corner akan memvalidasi email maka admin dari website Jeys Corner akan mendapat email bahwa ada pesanan baru. Pada gambar 2 adalah gambar dari activity diagram proses pemesanan produk.



\section{b. Proses Pembayaran}

Sesuai pesanan yang telah dibuat sebelumnya, pelanggan melakukan pembayaran melalui transfer bank sesuai dengan order details pada form checkout dan invoice yang dikirim ke email pelanggan. Kemudian pelanggan memilih menu Konfirmasi Pembayaran yang terdapat pada website Jeys Corner dan melakukan konfirmasi pembayaran dengan melengkapi form konfirmasi pembayaran serta mengupload bukti pembayaran. Kemudian pelanggan memilih tombol submit untuk mengirim form konfirmasi pembayaran beserta bukti pembayaran. Sistem akan memvalidasi konfirmasi pembayaran maka admin akan menerima email konfirmasi pembayaran dan sistem akan merubah status pesanan menjadi processing. Terlihat pada gambar 3 adalah gambar dari Activity Diagram proses pembayaran produk.

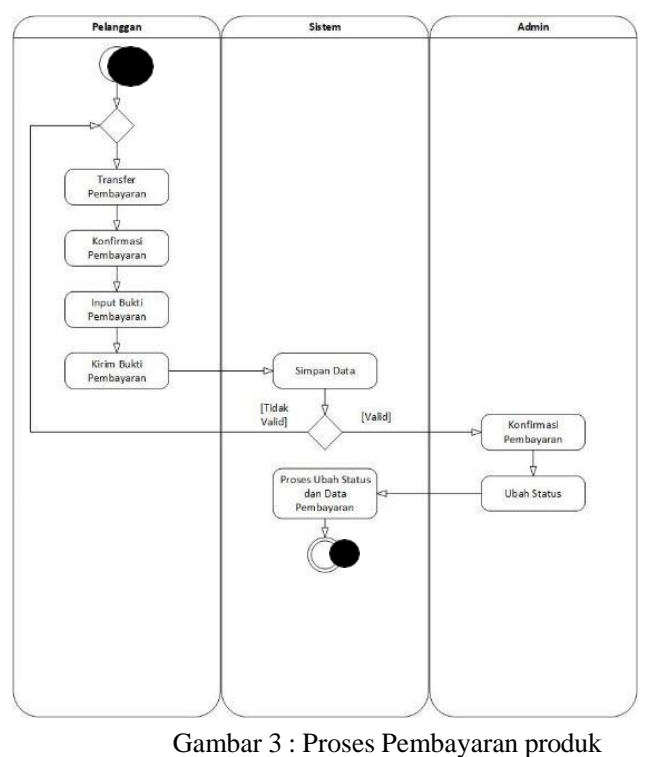

c. Proses Pengiriman

Setelah pelanggan melakukan konfirmasi pembayaran, admin melakukan pengemasan produk sesuai dengan pesanan pelanggan dan mengantarkan ke kantor jasa pengiriman yang sesuai dengan pilihan pelanggan. Setelah itu, admin akan menginput nomor resi pengiriman ke website Jeys Corner dan merubah status pesanan menjadi delivered dan sistem akan kirim email notifikasi delivered order kepada pelanggan. Pelanggan dapat melacak pesanannya di menu order pada halaman profil pelanggan di website Jeys Corner dengan menginput nomor resi di web jasa pengiriman yang bersangkutan. Gambar 4 adalah gambar dari Activity Diagram dari proses pengiriman produk.

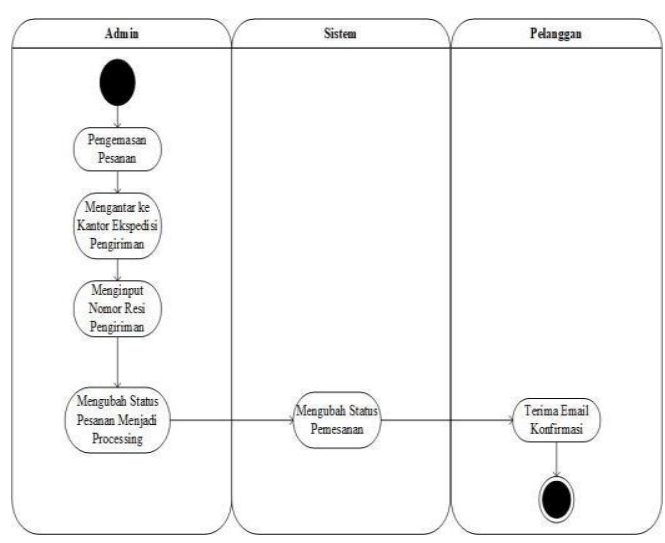

Gambar 4 : Proses Pengiriman produk

\subsection{Use Case Diagram}

Diagram yang menggambarkan fungsi yang diharapkan dari sebuah sistem. Sebuah Use Case mempresentasikan sebuah interaksi antara actor dengan sistem.

a. Use Case Diagram Master 
Gambar dibawah ini adalah gambar 5 merupakan Use Case Diagram Master terdiri dari actor pelanggan dan actor admin. Actor pelanggan register data dirinya untuk mendapat notif pendaftaran. Actor pelanggan bisa login jika sudah register. Kemudian di actor admin login terlebih dahulu untuk input produk, kategori, tags, dan coupun.



b. Use Case Diagram Transaksi

Gambar dibawah ini adalah gambar 6 yang merupakan use cae diagram transaksi terdiri dari actor pelanggan dan actor admin. Actor pelanggan bisa mengentry pemesanan dan bukti konfirmasi pembayaran. Pada sisi actor admin bisa validasi konfirmasi pembayaran, input no resi pengiriman dan menghitung total order.

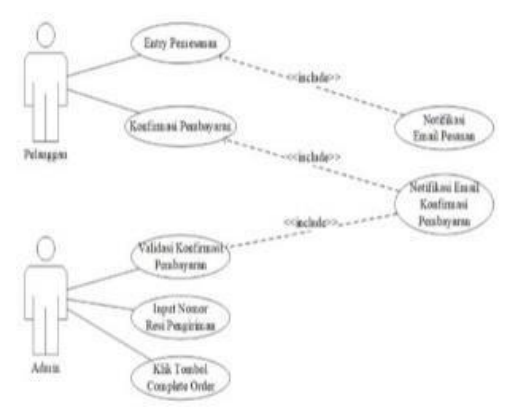

Gambar 6 : Use Case Transaksi

c. Use Case Diagram Laporan.

Gambar dibawah ini adalah gambar 7 yang merupaka use case diagram laporan terdiri dari actor admin dengan actor owner. Disini admin diharuskan mencetak laporan pemesanan, penjualan, pembayaran, pengiriman, dan produk terlaris yang kemudia diberikan kepada owner.

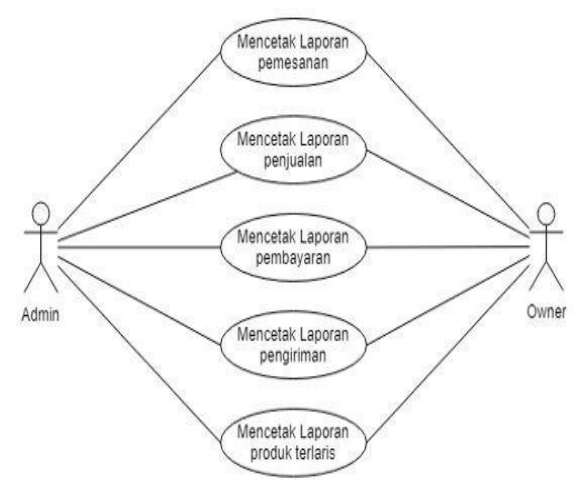

Gambar 7 : Use Case Laporan

\subsection{Rancangan Layar}

Rancangan layar adalah sebuah desain tampilan yang mempunyai fungsi sebagai antar muka pengguna dengan sistem, atau biasa disebut interface.

a. Gambar 8 yang terdapat di bawah ini adalah Rancangan Layar Registrasi dan Login Pelanggan. Halaman ini digunakan oleh pelanggan untuk mendaftar menjadi 
member atau login sebagai member.

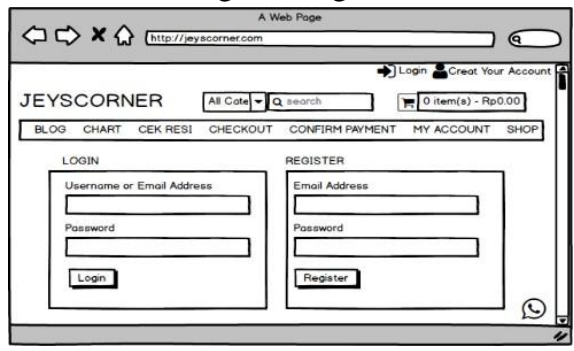

Gambar 8 : Rancangan layar Registrasi dan Login

b. Gambar 9 yang terdapat di bawah ini adalah gambar dari Rancangan Layar Pelanggan. Halaman tersebut digunakan untuk memilih produk yang ingin dibeli.

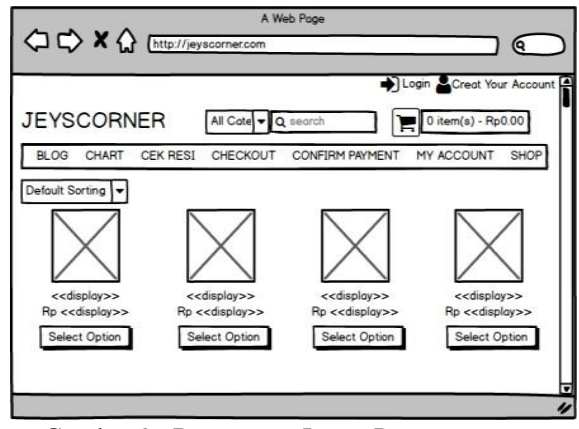

Gambar 9 : Rancangan Layar Pengguna

c. Gambar 10 yang terdapat di bawah ini adalah gambar dari Rancangan Layar Admin. Halaman ini digunakan admin untuk mengatur hal-hal yang berkaitan dengan toko.

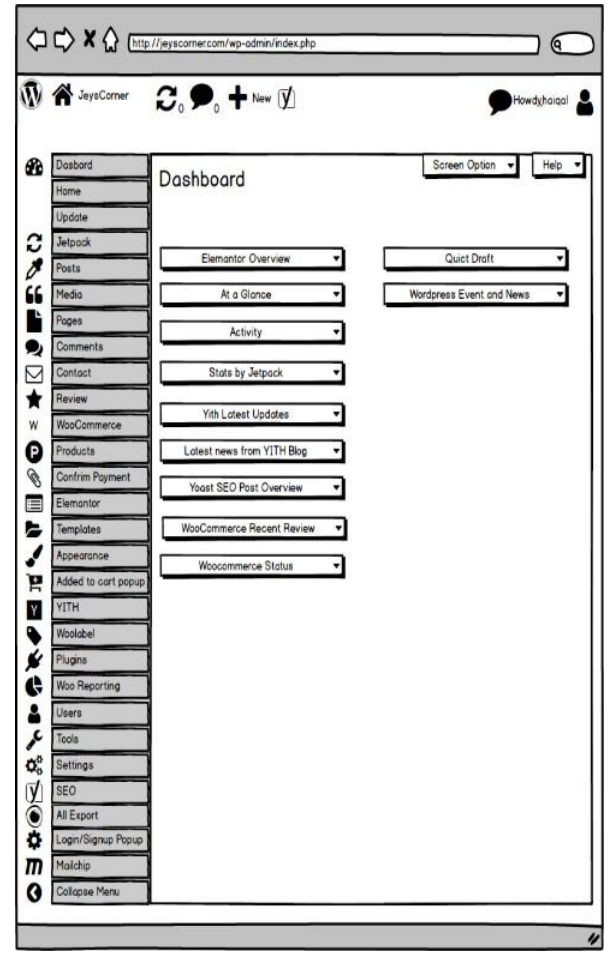

Gambar 10 : Rancangan Layar Admin d. Gambar 11 yang terdapat di bawah ini adalah gambar dari Rancangan Layar Sistem usulan keluaran email order yang akan diterima oleh pelanggan setelah proses checkout.



\section{KESIMPULAN}

Berdasarkan penelitian dan pembahasan ini telah dilakukan, dapat diambil kesimpulan sebagai berikut:

a. Dengan adanya fitur SEO dan marketing yang diterapkan pada sistem e-commerce Jeys Corner maka dapat memudahkan dalam hal menjual produk lebih luas, serta memperluas area promosi melalui pemasaran melalui internet dan google listing.

b. Dengan adanya fitur deskripsi produk yang ada pada e-commerce Jeys Corner maka calon customer tidak perlu menanyakan kembali pertanyaan dasar mengenai produk Jeys Corner

c. Dengan adanya fitur tampilan stok produk yang up to date kepada customer sehingga customer bisa langsung membeli produk tersebut tanpa perlu menanyakan stok ke admin Jeys Corner.

\section{DAFTAR PUSTAKA}

[1] Elinawati, S. dan Muhammad, A. 'Perancangan Content Management System (CMS) Dengan Studi Kasus E-Bisnis Pada Toko Alya', 2(1), 2015. ISSN : 2356-0010.

[2] [2015]Jogjakarta Intelligent System Association, D. A., Indonesian Computer, E. and I. S. S. and Universitas Gadjah Mada. Departemen Ilmu Komputer dan Elektronika, A.'Indonesian Journal of Computing and Cybernetics Systems.', Indonesian Journal of 
Computing and Cybernetics Systems, 9(2), pp. 145-156. Available At: https://repository.ugm.ac.id/136717/1/2015_20 15_sri_hartati_ik.pdf

[3] Mulyanto, A. 'Penerapan Teknologi RFID Modul RC522 Berbasis Raspberry Pi B + Pada Sistem Absensi Siswa di SMK At-Taqwa Cabangbungin Kabupaten Bekasi', Penerapan Teknologi RFID Modul RC522 Berbasis Raspberry Pi B + Pada Sistem Absensi Siswa di SMK At-Taqwa Cabangbungin Kabupaten Bekasi, 1(2), 2019. pp. 26-31. ISSN: 2541-3244

[4] Abdullah, D. 'Perancangan Sistem Informasi Pendataan Siswa SMP Islam Swasta Darul Yatama Berbasis Web', 4(1), 2015, pp. 39-44. p-ISSN: 2302-5700.

[5] [2016] Riyadi, N. dan Widjaja, A. 'Analisa dan Perancangan Sistem Informasi Administrasi Penilaiain Pada SMK Yapia Pondok Aren Dengan Metodologi Berorientasi Obyek', 8(2), pp. 153-162. Available At: https://journal.budiluhur.ac.id/index.php/telema tika/article/view/241/215

[6] [2016] Chandra, D.'Model Bisnis Pada Perusahaan X Menggunakan Business ModelCanvas',4(1),pp.18-25.

Available:http://publication.petra.ac.id/index.p hp/manajemenbisnis/article/view/4219 